i

\title{
子宮鏡下子宮内膜ポリープ切除術（TCR）後妊娠における癒着胎盤の 1 例 Placenta accreta in a woman with prior transcervical resection of endometrial polyps: a case report
}

\author{
大田原赤十字病院 産婦人科
}

佐藤健二、浅井 哲、末盛友浩、加藤直子、岩田 卓、白石 悟

\section{緒 言}

胎児婏出後も胎盤が婏出されず、胎盤の一部あ るいは全部が子宮筋層と癒着し、子宮腔内に遺残 する場合がある。これを癒着胎盤と呼び、しばし ば多量出血の原因となる。近年、子宮粘膜下筋腫 や子宮内膜ポリープなどの子宮腔内病変に対して は、レゼクトスコープに高周波電流を組み合わせ た子宮鏡下手術、経頸管的切除術 (transcervical resection: TCR）が低侵襲であり積極的に行われ ているが ${ }^{1)}$ 、TCR術後の妊娠例に癐着胎盤や前置 胎盤といった胎盤異常が合併症として報告されて いる。

今回、子宮内膜ポリープに対するTCR術後の 妊娠例で癒着胎盤となり多量出血をきたした症例 を経験したので、文献的考察を加え報告する。

\section{症例}

患者：35歳女性、1 経妊 1 経産

既往歴・家族歴：特記すべきことなし

現病歴：不正性器出血を主訴に当院を受診し、経 腟超音波検查にて $20 \mathrm{~mm}$ 大の子宮内腫瘍が疑わ れ、sonohysterographyと子宮鏡にて子宮内膜ポ リープと診断し、腰椎麻酔下にTCRを施行した。

術前検查所見

子宮頸部·体部細胞診：class II

血液検查：特記事項なし。

Sonohysterography：20mm大の子宮内腫瘍を認 如（図 1 )。

子宮鏡：右側壁から後壁にかけて内膜と接してお

り、表面平滑で異型血管なし。

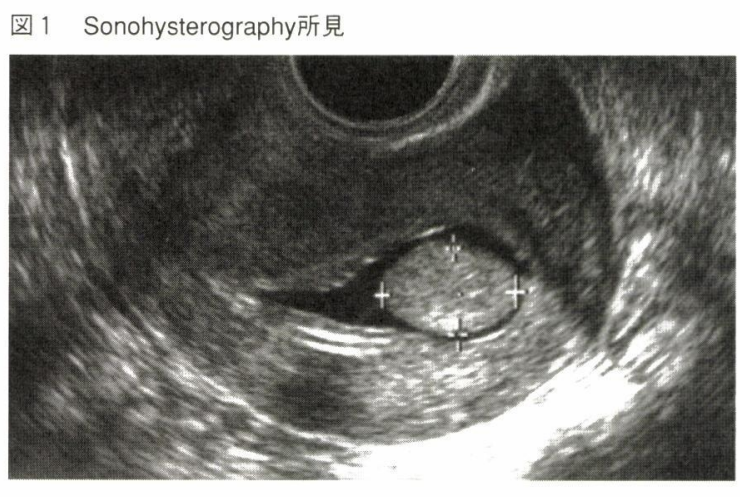

手術

施行日：平成15年12月日日

口 麻酔: 腰椎麻酔（腰椎3-4より塩酸ジブカイ ン $2 \mathrm{ml}$ 注入)

- 使用機器：オリンパス社製モノポーラ OES4000

(切除には70W、凝固には40Wを使用)

- 灌流液：3\% D-ソルビトール（ウロマチッ クS)

- 手術時間：41分

- 手術経過：子宮内腔を占拠するように子宮内 膜ポリープが認められ (四 2)、まず胎盤鉗 子にて大部分のポリープを摘除後、TCRの ループ型電極を用いて残存根部を切除した。 さらに切除部はローラー型電極にて凝固止血 した。術中著変なく、終了時に子宮腔内瘉着 防止のためIUD（FD-1）を挿入した。 


\section{図 2 TCR画像}

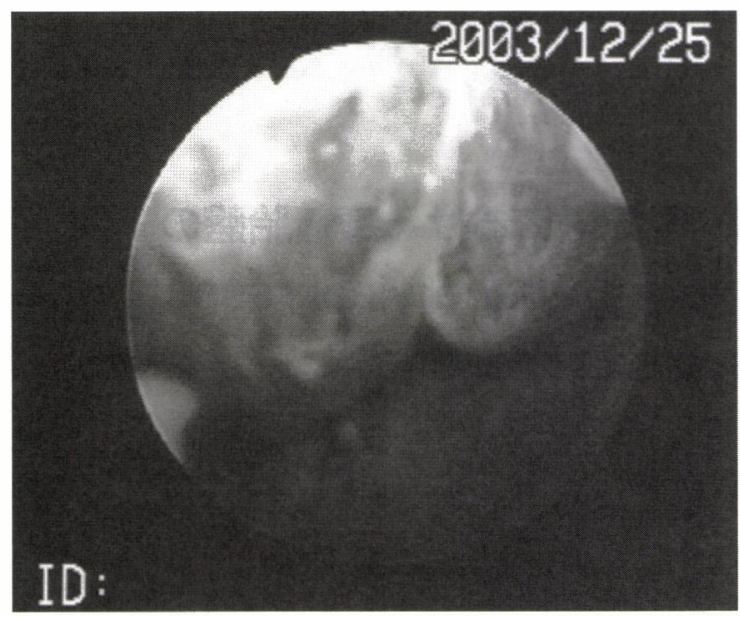

術後経過

術後経過良好で術後 4 日目 (平成口年口月日) に退院した。病理検査結果は子宮内膜ポリープ の診断であった。

術後 2 回目の月経後（平成16年 2 月回）に FD-1を抜去した。

平成16年 7 月曰日に妊娠反応陽性にて来院し た。

\section{妊娠・分娩経過}

妊娠経過は順調であった。

前回吸引分婏 (児体重 $3500 \mathrm{~g}$ ) であり、今回も 推定 $3500 \mathrm{~g}$ であったため、妊娠 38 週 3 日に分娩誘 発目的にて入院し、38週 4 日にアトニン点滴を施 行した。

陣痛開始後約 6 時間で子宮口は全開大し、経胵 分婏となった（男児、3590g、AP 9/9）。

\section{児婏出後の経過}

分婏後30分経過後も胎盤剥離徵候はみられず、 出血量が多くなってきたため、静脈麻酔下に用手 剥離術を施行した。

胎盤は子宮後壁を中心に癒着しており、用手的 に大部分を摘出後、腹部エコー下に胎盤鉗子を用 いて慎重に摘出し、さらにキュレットにて掻爬を 施行した。

分婏時の総出血量は $1790 \mathrm{~g}$ で $\mathrm{Hb} 6.7 \mathrm{~g} / \mathrm{dl}$ (分婏前 $\mathrm{Hb} 10.5 \mathrm{~g} / \mathrm{dl}$ ) まで低下したが、輸血はせず鉄剤投 与で回復し、分娭後 7 日目に退院となった。

血中hCGは、分婏 1 ケ月後に $6.2 \mathrm{mIU} / \mathrm{ml}$ であり、 2 ヶ月後には $1.2 \mathrm{mIU} / \mathrm{ml}$ 未満となった。

\section{考察}

癒着胎盤の定義は基底脱落膜の欠損あるいは形 成不全などにより、胎盤絨毛の一部または全部が 子宮筋層に直接付着または侵人しているものとさ れており、頻度は約2500分婏に1例である。臨床 診断は分娩時の胎盤剥離徵候の欠如および胎盤用 手剥離の困難による。また、確定診断は摘出子宮 または胎盤の病理検査による。

癒着胎盤のリスク因子は表 1 に示したとおりで

表 1 癒着胎盤のリスク因子

- 子宮の手術既往(帝王切開術。筋腫核出術, 子宮形成術, 子宮内膜ポリーブ切除術 など)

- 人工妊娠中絶や子宮内容除去術の既往

- 前置胎盤

- 子宮内膜炎の既往

- 子宮腺筋症や粘膜下筋腫の合併

あり、子宮内膜ポリープに対する TCR手術も含 まれる。TCR術後と癒着胎盤について文献的に 検索すると、癒着胎盤や前置胎盤といった胎盤異 常が妊娠成立後の合併症として認められるとの報 告がある ${ }^{2-4)}$ 。TCR手術痏痕部では脱落膜の発育 障害が起こる可能性があり、この部分に着床する と癒着胎盤を合併しやすいと考えられる。癒着胎 盤への対応としては、本症が疑われた場合は無理 な操作を加えず、超音波断層法やカラードプラ法、 場合によってはMRIを施行する。同時に緊急時に 備えての人員の確保や輸血の準備、さらに開腹術 に移行できるような体制を整える必要がある。そ のうえで試験的胎盤用手剥離を行うが、癒着が強 く剥離が困難な場合は嵌人胎盤や穿通胎盤の可能 性があり、その場合は剥離面からの出血を止血す ることは困難であるため、胎盤を無理に取り除か ないようにするべきである。本症例では胎盤用手 剥離はそれほど困難ではなかったことから、楔入 胎盤（placenta accreta）であったと考えられ、 胎盤剥離後は出血量も減少し、大事には至らなか ったが、もっと慎重に対応すべきであったと反省 している。本症例のように、TCRによる子宮内 膜ポリープ切除術では子宮筋層はほとんど切除さ れないが、粘膜下筋腫などの場合には筋層を深く 切除するため、嵌入胎盤や穿通胎盤も成立しえる と考えられ、よりいっそうの注意が必要と考えら れる。

TCR 術後の癒着胎盤防止策としては、まず術 中に子宮内膜や子宮筋層の切除を必要最小限に留 めることが重要である。また、手術終了時から FD-1などのIUDを挿入し、術後の子宮内腔癒着 を防止することも、子宮内膜の再生を促進するこ 
とにより癒着胎盤防止策となりうる。術後のカウ フマン療法については疑問視する報告が優勢であ $る^{5-7)}$ が、副作用も少なく、実際には使用してい る施設が多い。

挙児希望例では、術後に子宮鏡にて子宮内腔を 観察し、切除部の治癒を確認後に妊娠を許可する 必要がある。

妊娠中の癒着胎盤の診断は、近年では超音波断 層法、超音波ドプラ法、MRIなどの画像診断能力 の向上により、可能となっている ${ }^{8.9)}$ 。瘾着が軽 度のplacenta accreta では診断が困難であること も少なくないが、絨毛浸潤の深い重症例ほど診断 が容易であるとされており、TCR術後の妊娠例 では分娩前に腹部エコーで癒着胎盤の可能性を検 討し、必要があれば超音波ドプラ法やMRIにて精 査することが重要である。

\section{結 語}

TCR術後の妊娠例で癒着胎盤となった症例を 経験した。癒着胎盤はひとたび遭遇すると分婏後 の大量出血を引き起こし、対応が遅れれば母体死 亡に至ることもある。

したがって、TCR術後の妊娠例では癒着胎盤 の可能性があることを考慮し、分婏前における診 断と分婏時の対策が必要である。

本論文の要旨は第 45 回日本産科婦人科内視鏡学会 において発表した。

\section{参考文献}

1) Preutthipan S, Herabutya Y.: Hysteroscopic polypectomy in 240 premenopausal and postmenopausal women. Fertil Steril, 83:705-709,2005.

2) 石井彩ら：当院における挙児希望例に対する TCRの臨床成績、日産婦内視鏡誌、15:111-114、 1999.

3 ) Ewies AA, Mercer J, Phipps JH.: Intrauterine pregnancy complicated by placenta accreta after previous transcervical resection of endometrium. J Obstet Gynaecol 19:192-3, 1999.

4 ) Beuker JM, Erwich JJH, Khong TY.: Is endomyometrial injury during termination of pregnancy or curettage following miscarriage the precursor to placenta accreta? J Clin Pathol, 58:273-275, 2005.

5 ) Friedler S, et al:: Incidence of post-abortion intrauterine adhesions evaluated by hysteroscopy-a prospective study. Hum Reprod, 8:442-444, 1993.
6) Farhi J, et al.: Induced regeneration of endometrium following curettage for abortion: a comparative study. Hum Reprod, 8:1143-1144, 1993.

7 ) Romer T, Schmidt T, Foth D.: Pre- and postoperative hormonal treatment in patients with hysteroscopic surgery. Contrib Gynecol Obstet, 20:1$12,2000$.

8 ) Comstock $\mathrm{CH}$, et al:: Sonographic detection of placenta accreta in the second and third trimesters of pregnancy. Am J Obstet Gynecol, 190:11351140, 2004.

9 ) Levine D, et al.: Placenta accreta: Evaluation with color Doppler US, power Doppler US, and MR imaging. Radiology, 205:773-776, 1997. 